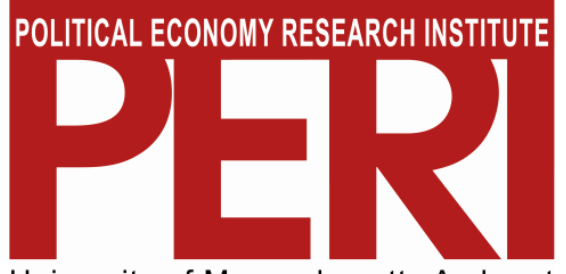

University of Massachusetts Amherst

Regional Variation in Environmental Inequality: Industrial air toxics exposure in U.S. cities

Klara Zwickl, Michael Ash, James K. Boyce

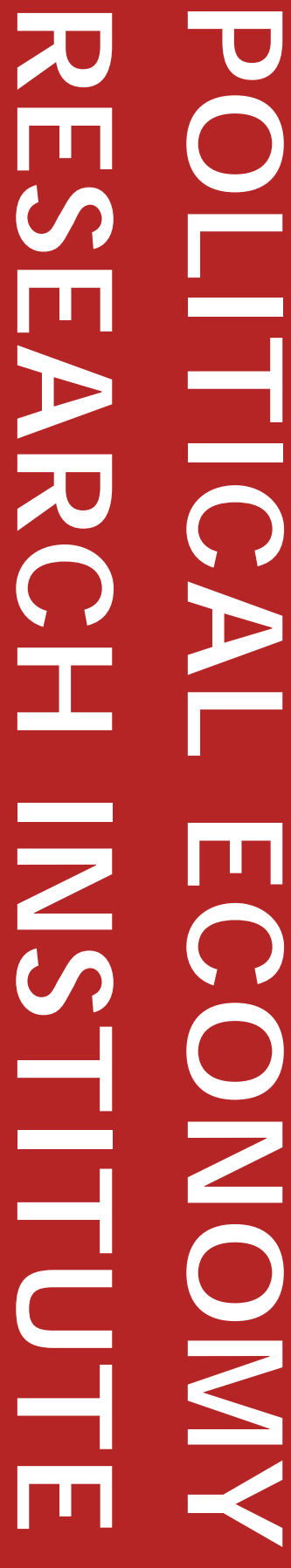

February 2014 


\title{
Regional variation in environmental inequality: Industrial air toxics exposure in U.S. cities
}

\author{
Klara Zwickl*, Michael Ash**, James K. Boyce***
}

February 19, 2014

\section{Abstract}

This paper analyzes how racial and ethnic disparities in exposure to industrial air toxics in U.S. cities vary with neighborhood income, and how these disparities vary regionally across the country. Exposure is estimated at the census block-group level using geographic microdata from the Risk-Screening Environmental Indicators of the U.S. Environmental Protection Agency (EPA). We find that racial and ethnic disparities in pollution exposure are strongest among neighborhoods with median incomes below $\$ 25,000$, while income-based disparities are stronger among neighborhoods with median incomes above that level. We also find considerable differences in the patterns of disparity across the ten EPA regions. In the two regions with the highest median exposure (the Midwest and South Central regions), for example, African-Americans and Hispanics face significantly higher exposures than whites, whereas in the region with the next highest exposure (the Mid-Atlantic), the reverse is true. We show that the latter result is attributable to intercity variations minorities tend to live in the less polluted cities in the region - rather than to within-city variations.

Keywords: Environmental inequality; environmental justice; air pollution, Risk-Screening Environmental Indicators.

JEL codes: I14, Q53, Q56, R11.

Funding from the National Science Foundation under Grant No. SES-1060904 is gratefully acknowledged. We thank Anita Milman, Simon Sturn and Owen Thompson for helpful comments on an earlier draft and Alexis Doyle for assistance in completing this study.

* Department of Economics, University of Massachusetts Amherst, kzwickl@econs.umass.edu

** Department of Economics, University of Massachusetts Amherst, mash@econs .umass .edu

*** Department of Economics and Political Economy Research Institute, University of Massachusetts Amherst, boyce@econs. umass .edu 


\section{Introduction}

This paper analyzes industrial air toxics exposure disparities by income, race and ethnicity in U.S. cities, here defined as urbanized areas within Core-Based Statistical Areas (CBSAs). Exposure estimates are obtained from the geographic microdata of the Risk-Screening Environmental Indicators (RSEI) of the U.S. Environmental Protection Agency (EPA). We merge the exposure data with U.S. Census data at the block-group level to obtain income and demographic variables. The fine level of geographic resolution provided by these data allows us to investigate two questions that have not been addressed in the literature on environmental inequality.

First, how do racial and ethnic disparities in exposure vary across neighborhoods with different levels of median income? Specifically, we test the hypothesis that racial and ethnic disparities in exposure decline with rising incomes. Because race and ethnicity are correlated with income, this could yield the result that racial and ethnic disparities in exposure are large across neighborhoods in the income strata where most people of color reside, but less pronounced across neighborhoods at the strata where most non-Hispanic whites reside.

Second, are there significant variations across the ten EPA regions in patterns of environmental inequality? Historical and institutional factors, including the nature of industrial development, patterns of immigration and the extent of racial segregation, vary across regions. Furthermore, the environmental standards and their enforcement vary across States, and there is evidence that State policies may influence those of neighboring States (Fredriksson and Millimet, 2002; Konisky, 2007). For these reasons, national-level analysis of environmental inequality may conceal important regional differences, and studies of specific regions or metropolitan areas may not be generalizable to the country as a whole.

The paper is organized as follows. After a brief literature review in the next section, we describe the data in more detail in section 3. Section 4 presents descriptive statistics on disparities in exposure at the national level and for the ten regions. Section 5 presents our model and estimation results, where we estimate the effects of income and minority status on exposure. Section 6 concludes.

\section{Literature Review}

After the release of the groundbreaking report by the Commission for Racial Justice (1987), which found strong racial disparities in proximity to hazardous waste facilities in the United States, national-level analysis of environmental disparities by race, ethnicity and income has generated a large and growing literature. A number of studies have analyzed the demographic correlates of proximity to toxics storage and disposal facilities (Anderton et al., 1994; Been and Gupta, 1997; Mohai and Saha, 2007; Bullard et al., 2008) or other environmental hazards (Hird and Reese, 1998; Mohai et al., 2009). Other studies have used information on proximity to industrial facilities in the EPA's Toxic Release Inventory, taking into account differences in 
emissions as well as residential locations (Perlin et al., 1995; Brooks and Sethi, 1997; Arora and Cason, 1999). An important methodological issue raised by these studies is the definition of proximity. When considering environmental hazards, how near is "near"? For example, Anderton et al. (1994) found that when proximity is defined very restrictively as residence in the same census tract in which a hazardous waste facility is located (these tend to be industrial tracts, with relatively low population density), there is no evidence of disproportionately high percentages of minorities. If, however, proximity is defined to include tracts within a 2.5-mile radius (which tend to be more densely populated), the percentages of minorities are significantly higher than average. ${ }^{1}$

More recent research has used data on exposure to pollution, rather than simple proximity to hazards (see for example Milman, 2006). By taking into account such factors as prevailing wind patterns, stack height and exit gas velocities, as well as the mass and toxicity of emissions, exposure-based analysis provides a more accurate picture of environmental inequalities, as well as a solution to the "how near is near" problem. National-level analyses of exposure disparities have relied mainly on data from the EPA's Risk-Screening Environmental Indicators (Bouwes et al., 2003; Ash and Fetter, 2004; Downey and Hawkins, 2008; Downey et al., 2008). ${ }^{2}$

Apart from these national-level studies, a number of researchers have analyzed environmental disparities in specific locations. For example, there have been studies of proximity to waste disposal sites in Houston (Bullard, 1983), metropolitan Detroit (Mohai and Bryant, 1992), Los Angeles county (Boer et al., 1997), Michigan (Saha and Mohai, 2005) and North Carolina (Norton et al., 2007). Others have examined proximity to industrial facilities covered by the Toxics Release Inventory in Ohio (Bowen et al., 1995), Southern California (Sadd et al., 1999), Minneapolis (Sheppard et al., 1999), Baltimore (Boone, 2002) and metropolitan Charleston (Wilson et al., 2012). Several exposure-based studies have also been conducted in specific locations: Sicotte and Swanson (2007) and Abel and White (2011) use RSEI data to examine industrial air toxics exposure disparities in Philadelphia and Seattle, respectively; Morello-Frosch et al. (2001) and Pastor et al. (2005) use National Air Toxics Assessment data to analyze exposure disparities in Southern California; Apelberg et al. (2005) use data from the same source in a study of Maryland; and Brochu et al. (2011) analyze disparities in exposure to airborne particular matter in the northeastern United States.

Notwithstanding differences in methodology and data sources, most of these studies have found evidence that racial and ethnic minorities and low-income communities tend to face disproportionate pollution hazards. There has been debate, however, over the relative importance of minority status and income in patterns of environmental inequality. Some studies have concluded that minority status dominates income (Commission

\footnotetext{
${ }^{1}$ In a more detailed analysis based on the same research project, Oakes (1997, p.122) observes that in neighborhoods one mile from TSDF tracts, the percentage of blacks is about 30\% - more than double the average, and that "past the two-mile point, the average [percentage black] falls fairly consistently until about five miles, when it becomes less than the mean percentage black for the whole sample." For discussion, see also Boyce (2007, pp.326-7).

${ }^{2}$ Exposure-based studies have also been conducted at the national level using EPA data on criteria air pollutants (MorelloFrosch and Jesdale, 2005; Bell and Ebisu, 2012).
} 
for Racial Justice, 1987; Mohai and Bryant, 1992; Been and Gupta, 1997; Lopez, 2002; Bullard et al., 2008; Marshall, 2008; Wilson et al., 2012). Indeed, some have found no significant income disparities after controlling for race and ethnicity (Perlin et al., 1995; Brooks and Sethi, 1997; Hird and Reese, 1998; Stretesky and Hogan, 1998; Houston et al., 2013). Others have reached the conclusion that income-related measures of socioeconomic status (such as poverty and education) are better predictors (Anderton et al., 1994; Bowen et al., 1995; Brochu et al., 2011) or that hazardous facilities tend to be located disproportionately in white working class neighborhoods (Boone, 2002).

While many studies have included both minority status and income as correlates of proximity or exposure to environmental hazards, few have investigated whether the effects of race and ethnicity vary across the income spectrum (or whether the effects of income vary with minority status). Ash et al. (2013), in a national-level analysis of exposure to industrial air toxics, report differences in exposure for non-poor whites, poor whites, non-poor minorities and poor minorities. Non-poor whites had the lowest median exposure and poor minorities had the highest. Poverty thus was associated with higher exposure among both whites and minorities, and minority status was associated with higher exposure among both the non-poor and the poor. In an analysis of exposure to hazardous air pollutants in California's South Coast Air Basin, Morello-Frosch et al. (2001) find that lifetime cancer risk declines for all groups as income rises. They find that people of color tend to face higher risk than whites at all income levels, but the gap between minorities and whites narrows in absolute terms as income rises. Apelberg et al. (2005) find that within the lowest median income quantile of census tracts in Maryland, cancer risk from exposure to air toxics rises significantly with the percentage of African-American residents, whereas race effects are considerably weaker in the other three quantiles. These findings from Southern California and Maryland suggest the hypothesis that racial and ethnic disparities are not constant across the income distribution, but instead are wider in the lower income strata. If so, multivariate models that assume racial and ethnic effects to be invariant across incomes are misspecified.

Owing to regional variations in history and institutions, it cannot be assumed that there is a "one size fits all" pattern of environmental disparities throughout the United States. Apart from differences in the methodologies and data employed, regional differences may contribute to the diversity of findings in case studies of specific locations. This has two implications for environmental justice research: on the one hand, case studies may not be generalizable; on the other hand, national studies that restrict estimated coefficients to be identical across regions can be biased.

A few national-level studies have drawn attention to the potential importance of inter-regional differences in patterns of environmental disparity. Anderton et al. (1994) disaggregate across the ten EPA regions in their examination of the demographic characteristics of census tracts in which toxic storage and disposal facilities are located. They find a statistically significant higher percentage of Hispanics only in Region 9 
(West/Southwest), but nowhere do they find a statistically higher percentage of blacks. Indeed, in Region 2 (Northeast) they find a significantly lower percentage of blacks residing in these tracts. They do not present region-specific findings on the demographics of surrounding tracts, which as noted above tend to have higher population densities and higher percentages of minorities. Perlin et al. (1995) note substantial differences across EPA regions in minority populations, income, and industrial emissions, from which they infer that environmental justice patterns are likely to vary across regions, too. In a comparison of median exposure of whites, blacks and Hispanics to industrial air toxics in the 61 largest U.S. metropolitan areas, Downey (2007) finds substantial variations in the extent of disparities, with the highest black/white exposure ratios generally found in the East North Central and East South Central census regions (corresponding to the contiguous belt of states from Wisconsin and Michigan in the north to Mississippi and Alabama in the south).

Although national-level analyses have the attraction of comprehensiveness, the most appropriate scale for thinking about the dynamics of environmental disparities may be the metropolitan area. When a firm or public agency makes facility siting decisions, it typically is choosing among locations within a given metropolitan area that has been chosen for reasons such as proximity to infrastructure, inputs or markets. Only then might we expect that inter-community differences in minority status or income become a consideration. Similarly, when people move out of a neighborhood in response to hazards, or move into a neighborhood in response to lower property values (or are channeled there by housing market discrimination), they typically do so within a given metropolitan area. Because national-level patterns reflect differences among metropolitan areas as well as within them, they do not necessarily give a clear picture of these dynamics. One way to isolate the variation within metropolitan areas is to employ spatial fixed effects in econometric models. Ash and Fetter (2004), who use such a specification for 1990s data, find that African-Americans tend to live both in the more polluted cities and in the more polluted areas within these cities, while Hispanics tend to live in the less polluted cities but within these cities "on the wrong sides of the environmental tracts," too. We use a similar model in this paper, but whereas Ash and Fetter restrict the estimated coefficients on minority status and income to be identical across the U.S., we allow them to vary across regions and between lower-income and higher-income neighborhoods.

\section{Data}

To measure industrial air toxics exposure, we use geographic microdata from the EPA's Risk Screening Environmental Indicators (RSEI) model for the year 2007. The RSEI model includes over 400 chemicals from more than 25,000 facilities in the manufacturing, mining, power generation, waste-management and chemical-management sectors, which are required to report their chemical releases to the Toxics Release Inventory (TRI). TRI was established under the Emergency Planning and Community Right-to-Know Act in 1986, after the 1984 chemical plant disaster in Bhopal, India, raised concerns about toxic releases in the U.S. 
The RSEI model includes a fate-and-transport model that uses information on stack heights, exit gas velocities, wind patterns, and chemical decay rates to estimate ambient concentrations of the toxic releases for 11,289 grid cells, each 810 meters square, around each facility. RSEI weights the chemicals by toxicity, defined in the case of air releases as chronic human health effects from inhalation exposure. Combining the toxicity-weighted ambient concentrations with census data on the size and age-sex composition of populations residing in each grid cell, the RSEI calculates a risk-screening indicator for each facility, aggregated across the grid cells impacted by its releases. Using geographic microdata at the grid cell level, researchers can also calculate toxicity-weighted ambient concentrations for each location, aggregated across all facilities whose releases impact that location. The RSEI model has been peer-reviewed by experts several times (US EPA, 2012).

While the RSEI data provide the best available measure of exposure to air toxics from industrial facilities, they only capture one part of overall air pollution. For example, the data do not include mobile sources (such as emissions from trucks, cars, and airplanes). Industrial point sources often loom large, however, in the communities that are at highest risk from air pollution (Boyce and Pastor, 2012).

This study uses RSEI geographic microdata for the year 2007, which are derived from the most recent version of the EPA's RSEI model (version 2.3.1). We obtain income and demographic variables from the 2000 U.S. Census. ${ }^{3}$ We merge Census data with the RSEI data at the Census block level and then aggregate the exposure scores to the blockgroup level, since this is the finest geographic resolution for which income variables are available in the Census. We limit our analysis to urbanized areas (more precisely, to blockgroups at least part of which are in an urbanized area), due to the differences between urbanized and rural areas in socioeconomic characteristics and industrial composition. ${ }^{4}$ To control for the influence of outliers, we censor the exposure variable at the 97 th percentile nationwide. ${ }^{5}$

Exposure to industrial air toxics is calculated as follows:

$$
E X P O S U R E_{j k r}=\frac{\sum_{k r}\left(E X P O S U R E_{i} * T O T A L P O P_{i} * X_{i j}\right)}{\sum_{k r}\left(T O T A L P O P_{i} * X_{i j}\right)}
$$

where

- subscript $j$ indexes population subgroups comprising minorities, non-Hispanic whites (hereafter simply "whites"), the poor (defined by the federal poverty line) and non-poor, based on Census headcount data;

- subscript $k$ indexes income groups, based on median blockgroup income;

\footnotetext{
${ }^{3}$ The seven-year lag between the demographic and pollution variables is not a major concern since the racial, ethnic and income characteristics of neighborhoods tend to change only gradually. Moreover, the lag is consistent with the hypothesis that the direction of causality runs primarily from population characteristics to exposure risks, rather than vice versa. For discussion of the "siting versus move-in" controversy, see Pastor et al. (2001) and Boyce (2007).

${ }^{4}$ Urbanized areas are defined as densely settled territories containing more than 50,000 people (US Census, 2007, A23). When we include rural areas, too, we generally find even wider exposure disparities. The results are available on request.

${ }^{5}$ Capping the exposure variable at this level reduces the population-weighted average blockgroup exposure score from 6840 to 4434 , reflecting the presence of strong outliers that could be due to reporting errors as well as exceptionally high pollution.
} 
- subscript $r$ indexes the 10 EPA regions (or all regions combines for national measures); ${ }^{6}$

- EXPOSURE $E_{i}$ is the RSEI exposure measure of blockgroup $i$;

- $T O T A L P O P_{i}$ is the total population in blockgroup $i$; and

- $X_{i j}$ is the share of subgroup $j$ in total blockgroup population.

EXPOSURE $E_{j k r}$ therefore is the population-weighted mean exposure of subgroup $j$ in income group $k$ in region $r .^{7}$

\section{Descriptive Statistics}

This section provides a descriptive overview of variations in average exposure to industrial air toxics by minority status, poverty status, and income. We first present national-level results, and then present comparable results for the ten EPA regions.

\subsection{National overview}

Figure 1 shows the national average exposure for four subgroups: non-poor whites, poor whites, non-poor minorities and poor minorities. ${ }^{8}$ Among both whites and minorities, the poor face higher average exposure than the non-poor, and among both the non-poor and the poor, minorities face higher exposure than whites. Average exposure for poor minorities is $29 \%$ higher than for non-poor whites.

Figure 1: Average Exposure by Poverty and Minority Status, National Level

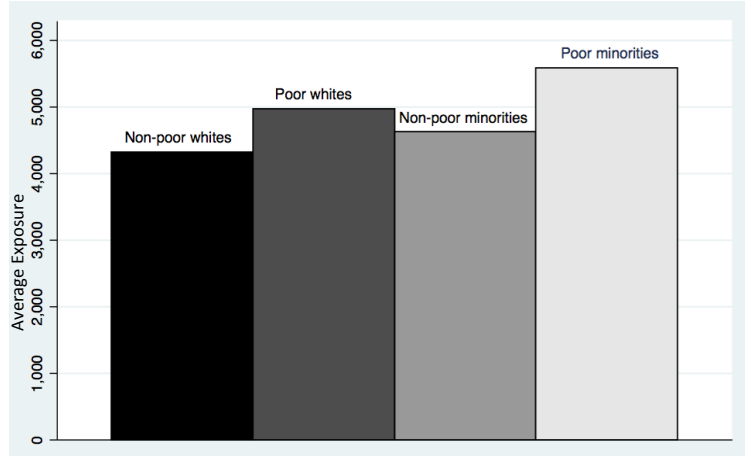

Note: Authors' calculations based on Equation 1
Figure 2: Average Exposure by Income and Race/Ethnicity, National Level

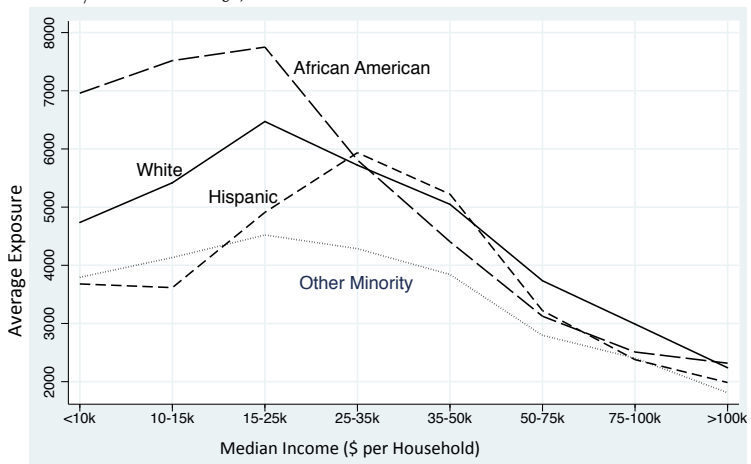

Note: Authors' calculations based on Equation 1

\footnotetext{
${ }^{6}$ In cases where a CBSA spans more than one EPA region, we assign it to the region that contains the largest share of the CBSA's population.

${ }^{7}$ Since our unit of observation in the study is the blockgroup, our measures do not take account of within-blockgroup variations in income or exposure.

${ }^{8}$ Poor households are households below the Census poverty line, which varies by size of family and number of related children under 18 years. For a family with two adults and two children, the poverty threshold in the 2000 census is $\$ 17,463$ (at 1999 dollars).
} 
To provide a finer-grained picture of exposure disparities, in Figure 2 we distinguish four racial/ethnic groups - non-Hispanic whites, African-Americans, Hispanics, and other minorities - and present their average exposure in eight median blockgoup income strata. For all four racial/ethnic groups, we find an inverted-U shaped relationship with income: in the lowest brackets, average exposure rises with income, but it declines after median blockgroup income reaches a level of about $\$ 25,000$ per household. This pattern is consistent with the findings of previous studies (Morello-Frosch et al., 2002, for example). The rising portion of the curves may reflect positive associations among industrial activity, incomes and pollution across cities, while the falling portion may reflect disparities in facility siting within cities.

A striking feature of Figure 2 is that minority status disparities are much wider in the lower-income strata. In the lowest income group, African-Americans have an average exposure $47 \%$ higher than that of whites. Hispanics and other minorities, on the other hand, have lower average exposures than whites. This reflects the fact that Hispanics and other minorities tend to live in cities with lower levels of industrial pollution. Within cities, however, Hispanics tend to face higher exposure than whites (Ash and Fetter, 2004). Above median blockgroup incomes of about $\$ 25,000$, differences in exposure are mainly associated with differences in income: for all four subgroups, exposure declines monotonically as income rises. Pollution exposure differences across lower-income neighborhoods thus appear to be strongly correlated with their racial/ethnic composition, whereas exposure differences among middle and upper-income neighborhoods are most strongly correlated with differences in income.

Table 1: Population distribution across median blockgroup incomes by race/ethnicity

\begin{tabular}{lcccc}
\hline Household income $(\$ 000)$ & White & African American & Hispanic & Other Minority \\
\hline \hline$<15 \mathrm{k}$ & $4.2 \%$ & $30.6 \%$ & $33.8 \%$ & $8.6 \%$ \\
$15-25 \mathrm{k}$ & $7.6 \%$ & $26.2 \%$ & $20.4 \%$ & $9.6 \%$ \\
$25-35 \mathrm{k}$ & $12.5 \%$ & $16.1 \%$ & $15.2 \%$ & $9.1 \%$ \\
$35-50 \mathrm{k}$ & $16.1 \%$ & $10.9 \%$ & $11.5 \%$ & $10.6 \%$ \\
$50-75 \mathrm{k}$ & $19.1 \%$ & $7.9 \%$ & $9.0 \%$ & $16.0 \%$ \\
$75-100 \mathrm{k}$ & $21.0 \%$ & $5.5 \%$ & $6.3 \%$ & $22.9 \%$ \\
$>100 \mathrm{k}$ & $19.5 \%$ & $2.8 \%$ & $3.8 \%$ & $23.1 \%$ \\
\hline LowInc & $34.3 \%$ & $73.5 \%$ & $67.0 \%$ & $48.1 \%$ \\
HighInc & $65.7 \%$ & $26.5 \%$ & $33.0 \%$ & $51.9 \%$ \\
\hline \hline
\end{tabular}

Note: LowInc refers to the percentage living in the poorer half of each city, HighInc to the percentage living in the richer half of the city.

Race/ethnicity and income themselves are strongly correlated, as shown in Table 1. More than half of African-Americans and Hispanics in urbanized areas live in blockgroups with median incomes under $\$ 25,000$, compared to fewer than $12 \%$ of whites. Combining this fact with the patterns seen in Figure 2, we can conclude that for most whites, neighborhood income appears to be the main correlate of disparities in exposure 
to industrial air pollution, whereas for most African-Americans, the racial composition of neighborhoods looms larger.

\subsection{Regional Variations}

There are substantial regional variations in exposure to industrial air toxics, as shown in Figure 3. The highest median exposures are in the EPA's Midwest, South Central, and Mid-Atlantic regions, in that order. These are also the top three regions when comparing the 75th and 90th percentiles of exposure. Disparities in exposure by race, ethnicity and income in these regions therefore are of particular interest.

Figure 3: Industrial Air Toxics Exposure by EPA region in U.S. cities

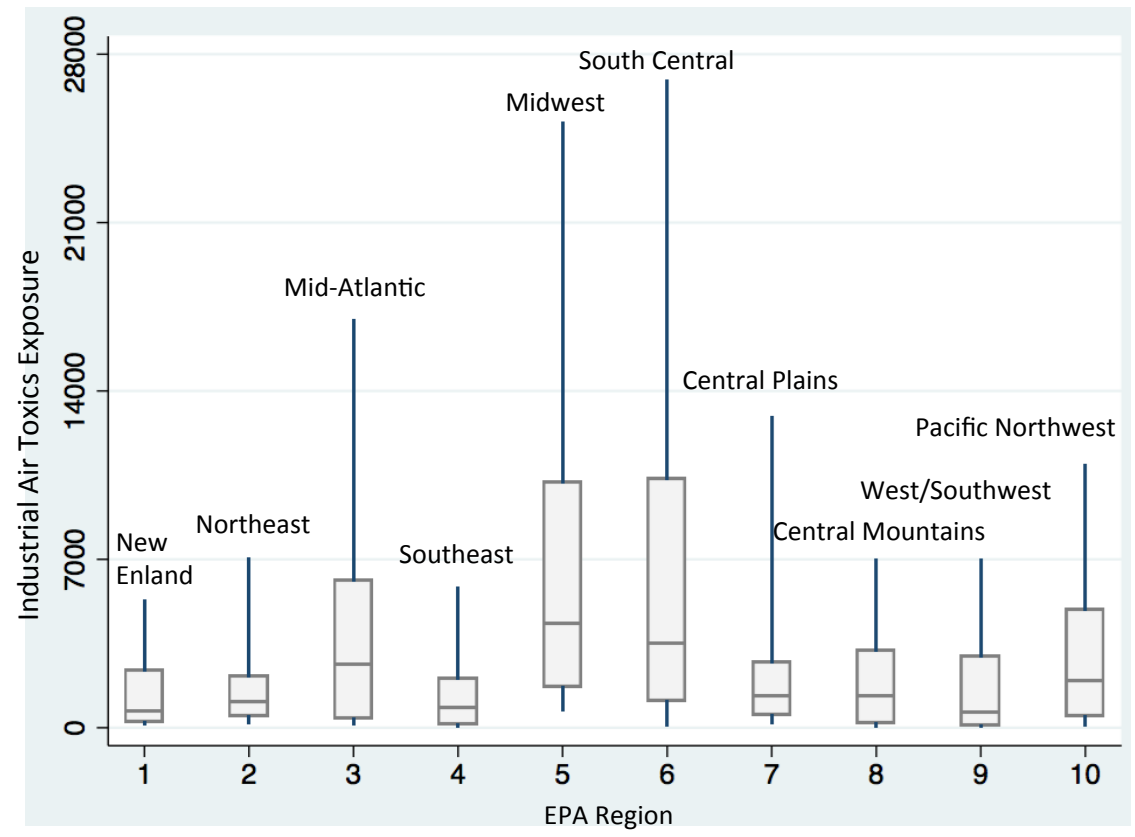

Note: The horizontal lines in the middle of each box represent the median exposure. The top and bottom edges of each box are the 25th and 75th percentile values. The vertical lines (whiskers) are drawn out to the 10th and 90th percentiles; observations beyond these values are not displayed.

Figure 4 shows average exposures by poverty and minority status for each of the ten EPA regions. ${ }^{9}$ The general patterns seen at the national level (in Figure 1) are also apparent at the regional level: poor minorities consistently have a higher average exposure than non-poor minorities; poor whites have a higher average exposure than non-poor whites in all regions but the Central Mountains and West/Southwest; poor minorities have a higher exposure risk than poor whites in all regions except for the Northeast, Mid-Atlantic and Central

\footnotetext{
${ }^{9}$ See Appendix Figure A.1 for definitions of the EPA regions.
} 
Plains; and non-poor minorities have a higher exposure risk than non-poor whites in all regions except for the Northeast and Mid-Atlantic.

Figure 4: Average Exposure by Poverty and Minority Status, EPA regions

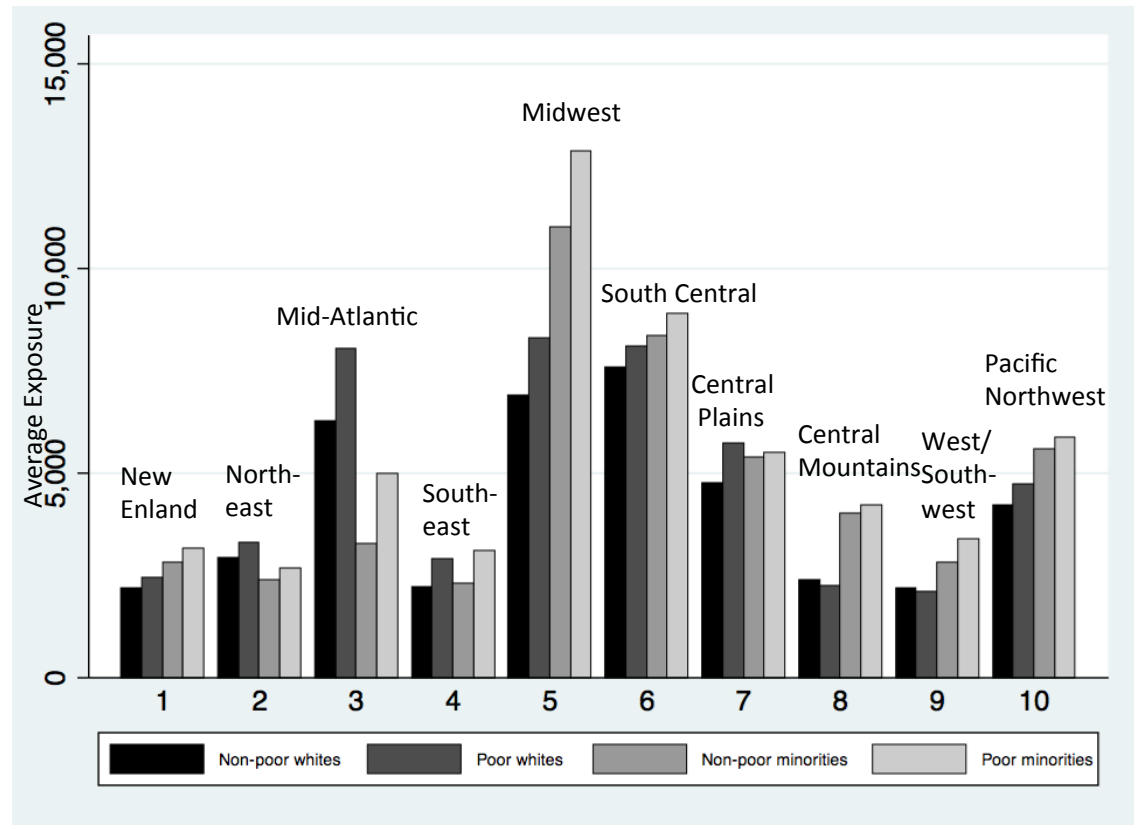

Note: Authors' calculations based on Equation 1

Among the three regions with the highest median exposure, the Mid-Atlantic is anomalous in that average exposure of whites exceeds average exposure of minorities. This suggests that patterns of disparity are subject to significant regional variations.

The importance of regional variations is still more apparent in Figure 5, which depicts average exposure for the four race/ethnicity groups across the eight income strata. In all regions there is some convergence across race/ethnicity groups as income rises. In the region with the highest overall exposure (Midwest), African-Americans and Hispanics have higher average exposure than whites throughout the income range. In the region with the second highest overall exposure (South Central), African-Americans have much higher average exposures than whites until they converge at an income level of roughly $\$ 50,000$, while Hispanics generally have lower average exposures than whites. In the Mid-Atlantic, the region with the third highest overall exposure, the pattern is quite different. Whites have a higher average exposure than African-Americans throughout the income range, and a higher exposure than Hispanics in all but the lowest two income brackets.

The results reported in this section reflect disparities among as well as within CBSAs. The econometric results presented in the next section allow us to compare disparities within cities to these overall disparities. 
Figure 5: Average Exposure by Income and Race/Ethnicity, EPA Regions
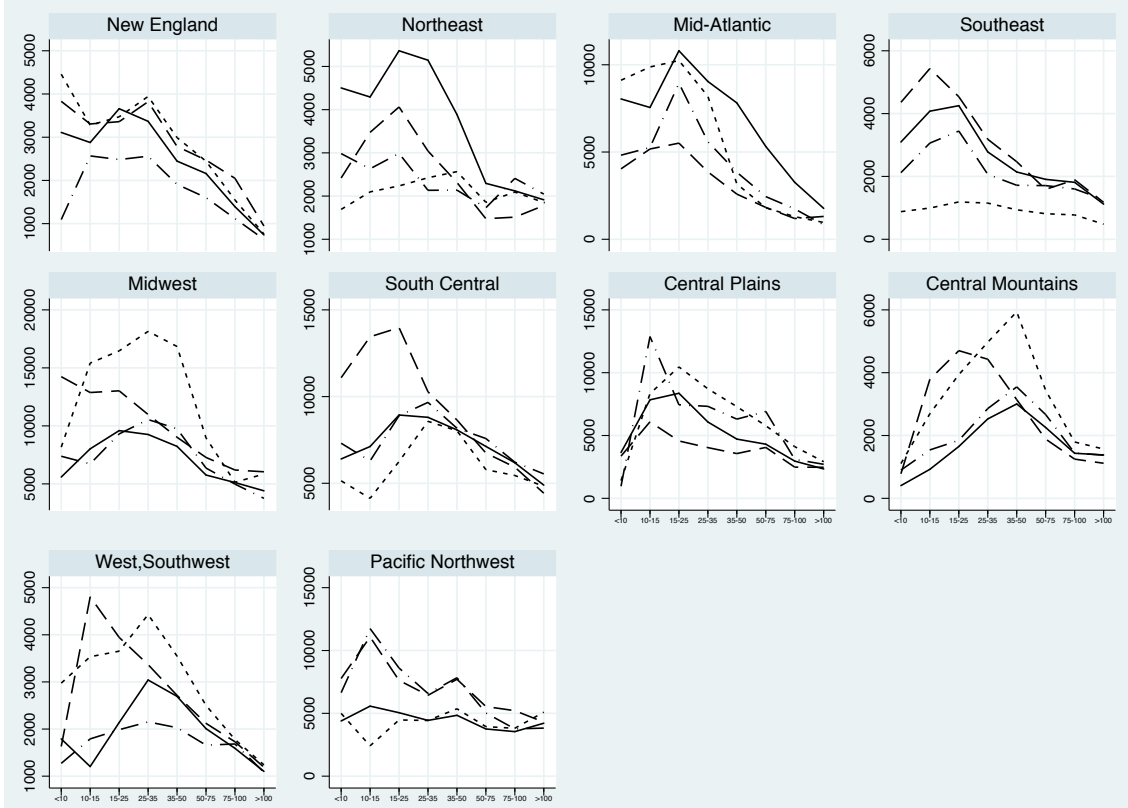

- ー - - African American

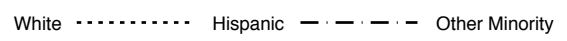

Note: Authors' calculations based on Equation 1. The vertical axes represent average exposure at region-specific scales.

\section{Econometric Analysis}

To shed further light on the relationships among industrial air pollution exposure, race/ethnicity, and income at both the national and regional levels, this section presents estimates of econometric models that allow us to examine not only the interactions between minority status and income but also to identify patterns of within-city variations by controlling for inter-city variations in exposure.

\subsection{Model}

We first estimate the following model:

$$
\ln \left(1+E X P O S U R E_{i c r}\right)=\beta_{0 r}+X_{i c r} * \beta_{X r}+k_{i c r} * \beta_{k}+k_{i c r}^{2} * \beta_{k^{2}}+\delta_{c}+\epsilon_{i c r}
$$

where EXPOSURE $E_{i c r}$ is the exposure of blockgroup $i$ in city $c$ in region $r ; X_{i c r}$ is a vector of variables indicating the percent of African Americans, Hispanics and other minorities in the population of the blockgroup; $f\left(k_{i c r}\right)$ is the median household income in the blockgroup; $\delta_{c}$ is a fixed effect for city $c$ in region $r$; and $\epsilon_{i j r}$ 
is the error term. Because the exposure variable is skewed to the left - many blockgroups have little or no industrial air pollution - we add 1 (to include observations with zero values) and take its logarithm. The quadratic term allows for concavity or convexity in the relationship between exposure and median income. ${ }^{10}$ The inclusion of city-specific fixed effects sweeps out between-city variation. For comparative purposes, we also present estimation results without city fixed effects. We weight by blockgroup population. To control for spatial autocorrelation, we cluster standard errors at the city level.

We then estimate a second model that splits the observations into blockgroups that are above and below the city's median income, to test whether race and ethnicity have different effects in the poorer versus richer halves of the city:

$\ln \left(1+E X P O S U R E_{i c r}\right)=\beta_{0 r}+X_{i c r} * L O W I N C_{i c r} * \beta_{X, L O W I N C, r}+X_{i c r} * H I G H I N C_{i c r} * \beta_{X, H I G H I N C, r}+\delta_{c}+\epsilon_{i c r}$

where $L O W I N C_{i c r}$ is a dummy variable that takes the value 1 if median income of the blockgroup is below the city average, and 0 otherwise; and $H I G H I N C_{i c r}$ takes the value 1 if median income of the blockgroup is above the city average, and 0 otherwise. Summary statistics for the variables used in the estimations at the national level and for the ten EPA regions are reported in Appendix Tables A.1 and A.2. The differences between mean and the median (p50) values in the percentages of whites and minorities, reported in Appendix Table A.1, is an indicator of widespread residential segregation. For example, the average blockgroup in U.S. cities has $13 \%$ African-Americans and 17\% Hispanics. Yet half of the blockgroups have only $3.2 \%$ or fewer African-Americans, and half have $5.4 \%$ or fewer Hispanics. There are substantial regional variations in the percentages of minorities, as shown in Appendix Table A.2. The percentage of African-Americans living in the average blockgroup varies from $3 \%$ in the Central Mountains to $21 \%$ in the Southeast, and the percentage of Hispanics varies from $4 \%$ in the Central Plains to $31 \%$ in the West/Southwest.

\section{$5.2 \quad$ Results}

The results of estimating equation 2 without fixed effects are reported in Table 2. At the national level and in eight of the ten EPA regions, the estimated coefficient for the African-American share of blockgroup population is positive and statistically significant. The coefficient at the national level is 0.93 , implying that controlling for income, exposure in an entirely African-American blockgroup would be $93 \%$ higher than in an all-white blockgroup (since whites are the omitted group in the model), and that a 10 percentage point increase in the number of African-Americans in a blockgroup, coupled with a 10 percentage point decrease in the number of whites, would be associated with a $9.3 \%$ increase in exposure. Only in the Mid-Atlantic region is the coefficient for African-American negative and statistically significant.

\footnotetext{
${ }^{10} \mathrm{We}$ also estimated specifications with dichotomous dependent variables, such as dummies for blockgroups in the top percentiles of exposure. In general, these produce results similar to those reported here.
} 
The results for Hispanics in this specification are mixed. In six regions the estimated coefficients for Hispanics are positive and statistically significant, but at the national level and in four regions it is negative and statistically significant, implying that in these cases as the percentage of Hispanics goes up, pollution exposure goes down. The results for other minorities are similar.

To assist in interpretation of the estimates of the quadratic income function, we report $f^{\prime}(0.5)$ - the slope at an income of $\$ 50,000$ - and the p-value for a joint significance test of the linear and quadratic terms at this income level. ${ }^{11}$ At the national level and in five regions, the slope is negative and statistically significant at $\$ 50,000$, indicating that as income goes up, pollution exposure declines. The slope of -0.15 at the national level implies that an increase of income from $\$ 50,000$ to $\$ 60,000$ decreases pollution exposure by $1.5 \%$. The slope on income at $\$ 50,000$ is positive and statistically significant in only two regions, the Central Mountains and the West/Southwest, both of which show relatively large disparities by race and ethnicity.

The results of estimating equation 2 with the inclusion of city-specific fixed effects are reported in Table 3. At the national level and in six of the regions, the coefficient for African-American is positive and statistically significant. Smaller coefficients, compared to those in the specification without fixed effects reported in Table 2, imply that both within and between city disparities contribute to overall exposure inequality. In New England, the Central Plains and the Central Mountains, the estimated coefficient for African-American is no longer statistically significant in the fixed-effects specification, suggesting that in these three regions disporportionate exposures of African-Americans are attributable mainly to between-city variations. In the Northeast, comparison of the results in Tables 2 and 3 shows that there are significant within-city disparities that are offset by opposing between-city variations in the model without fixed effects. Similarly, in the Mid-Atlantic, the negative and statistically significant reported coefficient in Table 2 can be seen to be entirely attributable to between-city variations, that is, to a tendency for African-Americnas to live in less polluted cities in this region.

\footnotetext{
${ }^{11}$ We also report the turning point of the quadratic function $\left(f^{\prime}=0\right)$. At the national level, we find an inverted-U relationship with a maximum at $\$ 38,600$. Again, however, we find substantial inter-regional differences. The Mid-Atlantic region, for example, shows a U-shaped relationship (rather than an inverted U) with a minimum at $\$ 202,000$, indicating that exposure diminishes throughout the income range.
} 
Table 2: Estimation Results without City Fixed Effects

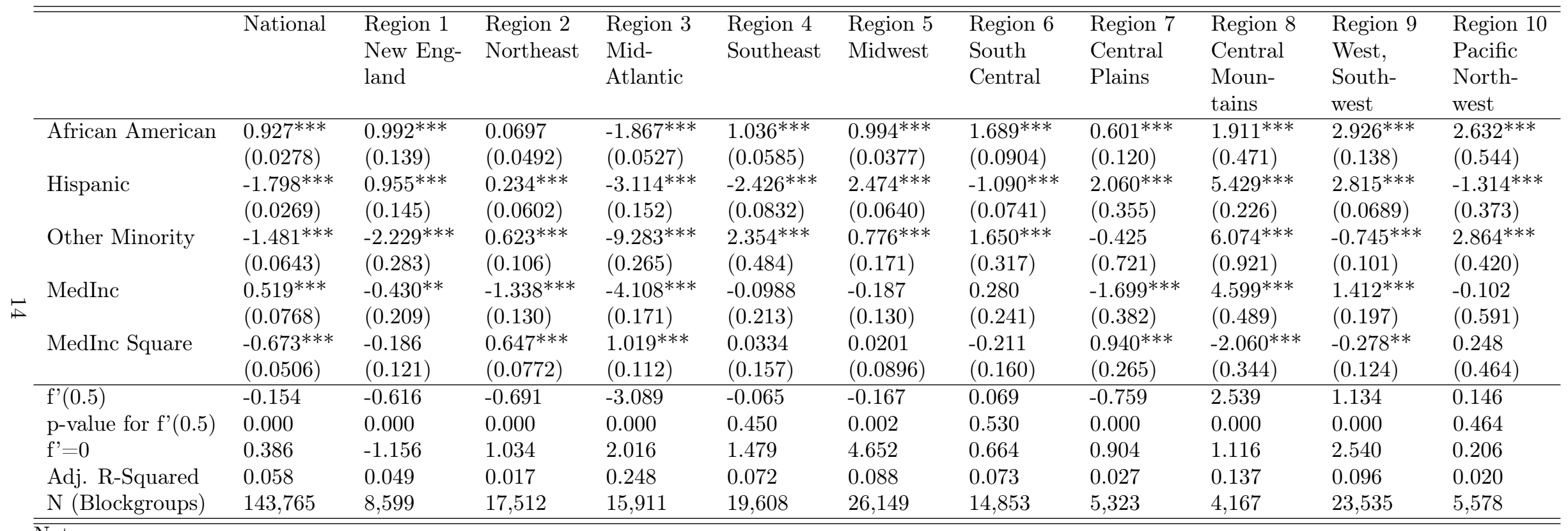

$$
\begin{aligned}
& \text { Notes: } \\
& * * * \mathrm{p}<0.01 \\
& * * \mathrm{p}<0.05 \\
& * \mathrm{p}<0.1
\end{aligned}
$$

(standard errors in parentheses) 
Table 3: Estimation Results with City Fixed Effects

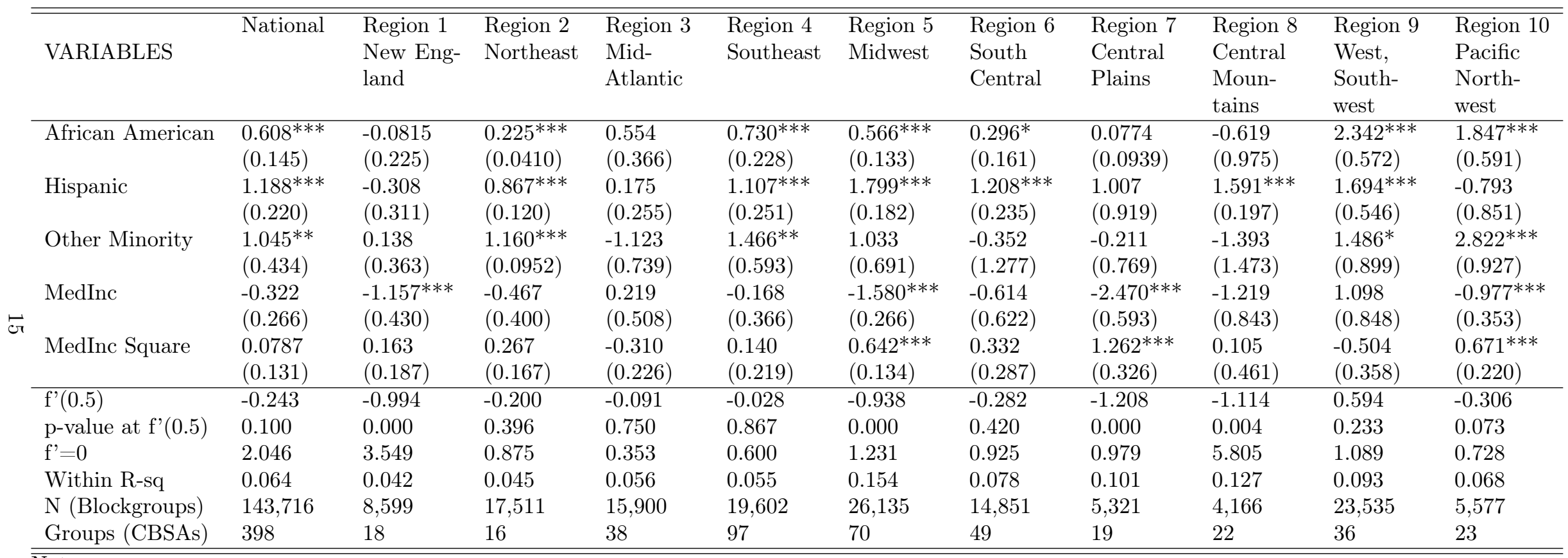

$$
\begin{aligned}
& \hline \text { Notes: } \\
& * * * \mathrm{p}<0.01 \\
& * * \mathrm{p}<0.05 \\
& * \mathrm{p}<0.1
\end{aligned}
$$

(robust standard errors in parentheses) 
For Hispanics at the national level and in the Southeast and South Central regions, the estimated coefficient is negative in Table 2 but positive in Table 3, indicating that while Hispanics tend to live in less polluted cities compared to whites, within these cities they tend to live in more polluted neighborhoods - a finding in line with that of Ash and Fetter (2004). However, results for Hispanics again vary considerably across regions. In the Mid-Atlantic and Pacific Northwest regions the coefficients are negative and statistically significant in Table 2, but no longer statistically significant in Table 3, suggesting that in these two regions Hispanics tend to live in the less polluted cities, and within these cities in areas with pollution comparable to that faced by whites. In four regions (Northeast, Midwest, Central Mountains and West/Southwest) Hispanics face higher pollution exposure both overall and within cities. In the two remaining regions (New England and Central Plains) Hispanics tend to live in the more polluted cities, but within these cities they do not face statistically significant exposure disparities. The national-level results for other minorities similarly imply that, like Hispanics, they tend to live in less polluted cities, but within these cities in more polluted neighborhoods. Again, however, these result are not generalizable to all regions.

The slope on the income term at $\$ 50,000$ at the national level is negative but barely significant at the $10 \%$ level. It is negative and statistically significant in five of the regions, and not statistically different from zero in the others.

To analyze the impacts of income in the absence of controls for minority status, we also re-estimated the fixed-effects model simply as a quadratic function of income. The results are reported in Table 4. At the national level and in every region, the estimated slope at $\$ 50,000$ is negative and statistically significant, ranging from -0.56 to -1.67 . At the national level the slope is -0.97 , implying that as the median income of the blockgroup goes up by $\$ 10,000$, exposure drops by $9.7 \%$. The stronger income effects without controls for minority status reflect the strong correlations between minority status and income seen in Table 1 and shown at the regional level in Appendix Figure A.2.

Finally, to test the hypothesis that minority status matters more for pollution exposure in lower-income neighborhoods, we estimated the model of equation 3 , in which the race and ethnicity variables are interacted with a dummy variable indicating whether median blockgroup income is below or above the CBSA average. Whites living in blockgroups with above-average incomes are the omitted group, so the estimated coefficients indicate how exposures vary compared to this reference group. ${ }^{12}$ We again include city fixed effects. The results are reported in Table 5.

At the national level, the coefficients are positive and statistically significant for all seven interaction terms. The coefficient of 0.17 for low-income whites implies that whites living in blockgroups with below-average incomes face $17 \%$ more exposure than whites living in blockgroups with above-average incomes. Across regions, the most consistent result is that the estimated coefficient for African-Americans living in lower-income

\footnotetext{
${ }^{12}$ Summary statistics for all variables are reported in Appendix Table A.2.
} 
neighborhoods is positive in all ten regions and statistically significant in all but one of them. At the national level, African-Americans living in the poorer half of the city have a $76 \%$ higher pollution exposure risk than whites living in the richer half. Strong findings also can be observed for Hispanics living in the poorer half of the city, for whom the estimated coefficients are positive and statistically significant in seven regions as well as at the national level. At the national level, compared to whites living in the richer half, Hispanics in the poorer half face a $133 \%$ higher pollution exposure. Whites living in the poorer half of the city face a significantly higher exposure in five regions, and other minorities living in the poorer half face significantly higher exposure in four regions. In no region do the residents of lower-income neighborhoods of any race or ethnicity face significantly lower exposure than whites living in upper-income neighborhoods.

The estimated coefficients for minorities living in upper-income neighborhoods are preponderantly positive, and in many cases statistically significant, implying that they too, often face higher exposures than whites living in upper-income neighborhoods. For African-Americans the coefficients are positive and statistically significant in four regions; for Hispanics, in seven; and for other minorities, in four. Negative and statistically significant coefficients are found only in two cases, one for Hispanics and one for other minorities.

These results are broadly consistent with the hypotheses that both minority status and income matter for pollution exposure, and that the effects of minority status tend to be stronger among neighborhoods in the lower half of the income spectrum - which is where most minorities live. There are considerable variations across regions, however. In the two regions with the highest average exposure to industrial air pollution - the Midwest and South Central regions - the estimated coefficients for African-Americans and Hispanics in the lower-income half of the city are consistently higher than for those in the higher-income half. 
Table 4: Estimation Results with City Fixed Effects only Income

\begin{tabular}{|c|c|c|c|c|c|c|c|c|c|c|}
\hline National & $\begin{array}{l}\text { Region } 1 \\
\text { New Eng- } \\
\text { land }\end{array}$ & $\begin{array}{l}\text { Region } 2 \\
\text { Northeast }\end{array}$ & $\begin{array}{l}\text { Region } 3 \\
\text { Mid- } \\
\text { Atlantic }\end{array}$ & $\begin{array}{l}\text { Region } 4 \\
\text { Southeast }\end{array}$ & $\begin{array}{l}\text { Region } 5 \\
\text { Midwest }\end{array}$ & $\begin{array}{l}\text { Region } 6 \\
\text { South } \\
\text { Central }\end{array}$ & $\begin{array}{l}\text { Region } 7 \\
\text { Central } \\
\text { Plains }\end{array}$ & $\begin{array}{l}\text { Region } 8 \\
\text { Central } \\
\text { Moun- } \\
\text { tains }\end{array}$ & $\begin{array}{l}\text { Region } 9 \\
\text { West, } \\
\text { South- } \\
\text { west }\end{array}$ & $\begin{array}{l}\text { Region } 10 \\
\text { Pacific } \\
\text { North- } \\
\text { west }\end{array}$ \\
\hline$-1.494^{* * *}$ & $-0.918^{* * *}$ & $-1.335^{* * *}$ & $-0.537^{*}$ & $-1.353^{* * *}$ & $-2.810^{* * *}$ & $-1.874^{* * *}$ & $-2.765 * * *$ & $-2.104^{* *}$ & $-1.139 * *$ & $-1.432^{* *}$ \\
\hline$(0.189)$ & $(0.221)$ & $(0.252)$ & $(0.300)$ & $(0.364)$ & $(0.439)$ & $(0.462)$ & $(0.458)$ & $(0.874)$ & $(0.558)$ & $(0.724)$ \\
\hline $0.526^{* * *}$ & 0.0629 & $0.587^{* * *}$ & -0.0175 & $0.641^{* * *}$ & $1.151^{* * *}$ & $0.795^{* * *}$ & $1.400 * * *$ & 0.430 & 0.271 & $0.870^{*}$ \\
\hline$(0.0938)$ & $(0.137)$ & $(0.112)$ & $(0.148)$ & $(0.182)$ & $(0.186)$ & $(0.210)$ & $(0.260)$ & $(0.484)$ & $(0.237)$ & $(0.461)$ \\
\hline-0.968 & -0.855 & -0.748 & -0.555 & -0.712 & -1.659 & -1.079 & -1.365 & -1.674 & -0.868 & -0.562 \\
\hline 0.000 & 0.000 & 0.000 & 0.001 & 0.001 & 0.000 & 0.000 & 0.000 & 0.000 & 0.014 & 0.035 \\
\hline 1.420 & 7.297 & 1.137 & -15.343 & 1.055 & 1.221 & 1.179 & 0.988 & 2.447 & 2.101 & 0.823 \\
\hline 0.032 & 0.041 & 0.021 & 0.026 & 0.017 & 0.102 & 0.041 & 0.095 & 0.092 & 0.018 & 0.009 \\
\hline 143,716 & 8,599 & 17,511 & 15,900 & 19,602 & 26,135 & 14,851 & 5,321 & 4,166 & 23,535 & 5,577 \\
\hline 398 & 18 & 16 & 38 & 97 & 70 & 49 & 19 & 22 & 36 & 23 \\
\hline
\end{tabular}

$$
\begin{aligned}
& \text { Notes: } \\
& * * * \mathrm{p}<0.01 \\
& * * \mathrm{p}<0.05 \\
& * \mathrm{p}<0.1
\end{aligned}
$$

(robust standard errors in parentheses) 
Table 5: Estimation Results with Race, Ethnicity and Income Interaction Effects

\begin{tabular}{|c|c|c|c|c|c|c|c|c|c|c|c|}
\hline VARIABLES & National & $\begin{array}{l}\text { Region } 1 \\
\text { New Eng- } \\
\text { land }\end{array}$ & $\begin{array}{l}\text { Region } 2 \\
\text { Northeast }\end{array}$ & $\begin{array}{l}\text { Region } 3 \\
\text { Mid- } \\
\text { Atlantic }\end{array}$ & $\begin{array}{l}\text { Region } 4 \\
\text { Southeast }\end{array}$ & $\begin{array}{l}\text { Region } 5 \\
\text { Midwest }\end{array}$ & $\begin{array}{l}\text { Region } 6 \\
\text { South } \\
\text { Central }\end{array}$ & $\begin{array}{l}\text { Region } 7 \\
\text { Central } \\
\text { Plains }\end{array}$ & $\begin{array}{l}\text { Region } 8 \\
\text { Central } \\
\text { Moun- } \\
\text { tains }\end{array}$ & $\begin{array}{l}\text { Region } 9 \\
\text { West, } \\
\text { South- } \\
\text { west }\end{array}$ & $\begin{array}{l}\text { Region } 10 \\
\text { Pacific } \\
\text { North- } \\
\text { west }\end{array}$ \\
\hline White*LowInc & $\begin{array}{l}0.170^{* * *} \\
(0.0348)\end{array}$ & $\begin{array}{l}0.309^{* * *} \\
(0.0866)\end{array}$ & $\begin{array}{l}0.216^{*} \\
(0.118)\end{array}$ & $\begin{array}{l}0.0187 \\
(0.0781)\end{array}$ & $\begin{array}{l}0.000865 \\
(0.0859)\end{array}$ & $\begin{array}{l}0.381^{* * *} \\
(0.0581)\end{array}$ & $\begin{array}{l}0.0426 \\
(0.0919)\end{array}$ & $\begin{array}{l}0.493^{* * *} \\
(0.105)\end{array}$ & $\begin{array}{l}0.453^{* * *} \\
(0.137)\end{array}$ & $\begin{array}{l}-0.127 \\
(0.147)\end{array}$ & $\begin{array}{l}-0.0721 \\
(0.0457)\end{array}$ \\
\hline African American* LowInc & $\begin{array}{l}0.761^{* * *} \\
(0.119)\end{array}$ & $\begin{array}{l}0.372^{* * *} \\
(0.138)\end{array}$ & $\begin{array}{l}0.418^{* * *} \\
(0.124)\end{array}$ & $\begin{array}{l}0.531^{* *} \\
(0.245)\end{array}$ & $\begin{array}{l}0.785^{* * *} \\
(0.194)\end{array}$ & $\begin{array}{l}0.992^{* * *} \\
(0.126)\end{array}$ & $\begin{array}{l}0.476^{* * *} \\
(0.178)\end{array}$ & $\begin{array}{l}0.718^{* * *} \\
(0.0829)\end{array}$ & $\begin{array}{l}0.380 \\
(0.767)\end{array}$ & $\begin{array}{l}2.250^{* * *} \\
(0.329)\end{array}$ & $\begin{array}{l}1.379^{* *} \\
(0.606)\end{array}$ \\
\hline African American*HighInc & $\begin{array}{l}0.620^{* * *} \\
(0.189)\end{array}$ & $\begin{array}{l}0.774 \\
(0.635)\end{array}$ & $\begin{array}{l}0.00893 \\
(0.122)\end{array}$ & $\begin{array}{l}0.857 \\
(0.593)\end{array}$ & $\begin{array}{l}0.672^{* *} \\
(0.275)\end{array}$ & $\begin{array}{l}0.799^{* * *} \\
(0.0819)\end{array}$ & $\begin{array}{r}-0.0357 \\
(0.142)\end{array}$ & $\begin{array}{l}0.140 \\
(0.300)\end{array}$ & $\begin{array}{l}-1.718 \\
(1.470)\end{array}$ & $\begin{array}{l}1.690^{* *} \\
(0.694)\end{array}$ & $\begin{array}{l}2.626^{* * *} \\
(0.609)\end{array}$ \\
\hline Hispanic*LowInc & $\begin{array}{l}1.331^{* * *} \\
(0.196)\end{array}$ & $\begin{array}{l}0.330 \\
(0.204)\end{array}$ & $\begin{array}{l}1.039^{* * *} \\
(0.0297)\end{array}$ & $\begin{array}{l}0.317 \\
(0.208)\end{array}$ & $\begin{array}{l}1.156^{* * *} \\
(0.246)\end{array}$ & $\begin{array}{l}2.215^{* * *} \\
(0.154)\end{array}$ & $\begin{array}{l}1.314^{* * *} \\
(0.155)\end{array}$ & $\begin{array}{l}1.485^{*} \\
(0.812)\end{array}$ & $\begin{array}{l}2.134^{* * *} \\
(0.232)\end{array}$ & $\begin{array}{l}1.423^{* * *} \\
(0.411)\end{array}$ & $\begin{array}{l}-0.739 \\
(0.783)\end{array}$ \\
\hline ๑Hispanic*HighInc & $\begin{array}{l}1.442^{* * * *} \\
(0.237)\end{array}$ & $\begin{array}{c}-0.0914 \\
(0.808)\end{array}$ & $\begin{array}{l}0.712^{* * *} \\
(0.259)\end{array}$ & $\begin{array}{l}-1.300^{* * *} \\
(0.495)\end{array}$ & $\begin{array}{l}1.106^{* * *} \\
(0.157)\end{array}$ & $\begin{array}{l}1.688^{* * *} \\
(0.125)\end{array}$ & $\begin{array}{l}1.263^{* * *} \\
(0.242)\end{array}$ & $\begin{array}{l}3.885^{* *} \\
(1.743)\end{array}$ & $\begin{array}{l}3.726^{* * *} \\
(0.730)\end{array}$ & $\begin{array}{l}1.911^{* * *} \\
(0.439)\end{array}$ & $\begin{array}{l}-1.738 \\
(1.363)\end{array}$ \\
\hline Other Minority*LowInc & $\begin{array}{l}0.919^{* * *} \\
(0.315)\end{array}$ & $\begin{array}{l}0.658 * * \\
(0.279)\end{array}$ & $\begin{array}{l}0.809^{* * *} \\
(0.0402)\end{array}$ & $\begin{array}{l}-0.763 \\
(0.846)\end{array}$ & $\begin{array}{l}0.467 \\
(0.502)\end{array}$ & $\begin{array}{l}1.157 \\
(0.864)\end{array}$ & $\begin{array}{c}-0.253 \\
(0.993)\end{array}$ & $\begin{array}{c}-0.132 \\
(0.733)\end{array}$ & $\begin{array}{l}-0.685 \\
(0.832)\end{array}$ & $\begin{array}{l}1.232^{*} \\
(0.698)\end{array}$ & $\begin{array}{l}3.644^{* * *} \\
(0.672)\end{array}$ \\
\hline Other Minority*HighInc & $\begin{array}{l}1.361^{* *} \\
(0.582)\end{array}$ & $\begin{array}{c}-0.0760 \\
(0.577)\end{array}$ & $\begin{array}{l}2.286^{* * *} \\
(0.142)\end{array}$ & $\begin{array}{l}-1.540^{* * *} \\
(0.493)\end{array}$ & $\begin{array}{l}2.550^{* *} \\
(1.019)\end{array}$ & $\begin{array}{l}1.499^{* * *} \\
(0.285)\end{array}$ & $\begin{array}{l}-0.217 \\
(1.510)\end{array}$ & $\begin{array}{l}0.798 \\
(0.865)\end{array}$ & $\begin{array}{l}-1.880 \\
(2.382)\end{array}$ & $\begin{array}{l}1.545 \\
(1.014)\end{array}$ & $\begin{array}{l}1.192 \\
(1.290)\end{array}$ \\
\hline Within R-sq & 0.065 & 0.026 & 0.052 & 0.056 & 0.056 & 0.154 & 0.080 & 0.097 & 0.122 & 0.094 & 0.078 \\
\hline N (Blockgroups) & 143,716 & 8,599 & 17,511 & 15,900 & 19,602 & 26,135 & 14,851 & 5,321 & 4,166 & 23,535 & 5,577 \\
\hline CBSAs & 398 & 18 & 16 & 38 & 97 & 70 & 49 & 19 & 22 & 36 & 23 \\
\hline
\end{tabular}

Notes:

$* * * \mathrm{p}<0.01$

$* * \mathrm{p}<0.05$

$* \mathrm{p}<0.1$

(robust standard errors in parentheses) 


\section{Conclusion}

This study has explored inequalities in the distribution of industrial air pollution by estimating neighborhood exposure as a function of minority status, income and interactions between the two, at the national level and in the ten EPA regions. We find that exposure varies with minority status most strongly among neighborhoods with median household incomes below $\$ 25,000$, whereas variations in neighborhood income matter more above $\$ 25,000$. Most minorities reside in the former, while most non-Hispanic whites reside in the latter. Perceptions as to the relative importance of minority status and income as correlates of pollution exposure therefore may vary between minorities and whites.

At the national level, minorities living in the lower-income half of their city face significantly higher exposures than whites living in the upper-income half. The same is true in most regions: for AfricanAmericans, the difference is statistically significant in nine of the ten regions, for Hispanics in seven, and for

other minorities in four. In no region do we find exposures of minorities in lower-income neighborhoods to be significantly lower than those of whites in upper-income neighborhoods. At the national level, and in five of the regions, whites living in the lower-income half of the city also face significantly higher exposures than whites living in the upper-income half, and in no region do they face significantly lower exposures. These findings confirm the enduring salience of race, ethnicity and household income as correlates of air quality in the United States.

The results reveal marked variations in regional patterns of environmental inequality, however, and these may help to explain some of the divergent findings of studies that have focused on specific regions or metropolitan areas. For example, we find that exposures of African-Americans are significantly higher than those of whites in the Midwest and South Central regions (the two with the highest average exposure levels), but we find the opposite in the Mid-Atlantic region (which ranks third), a result attributable solely to differences among cities in the Mid-Atlantic regions rather than within them.

Similarly, comparing the two regions with the largest Hispanic population shares, we find that Hispanics in the West/Southwest tend to live both in more polluted cities and in more exposed neighborhoods within them, whereas in the South Central region they tend to live in less polluted cities but again in more polluted neighborhoods within a given city.

Further research is necessary to understand the reasons for these regional differences and their implications for environmental policy. A relevant question is to what extent the regional variations reported here are an outcome of industrial siting decisions and to what extent they reflect differential enforcement of environmental standards within regions. 


\section{References}

Abel, T. D. and White, J. (2011). Skewed riskscapes and gentrified inequities: environmental exposure disparities in Seattle, Washington. American Journal of Public Health, 101 Suppl:S246-54.

Anderton, D. L., Anderson, A. B., Oakes, J. M., and Fraser, M. R. (1994). Environmental equity: the demographics of dumping. Demography, 31(2):229-48.

Apelberg, B. J., Buckley, T. J., and White, R. H. (2005). Socioeconomic and Racial Disparities in Cancer Risk from Air Toxics in Maryland. Environmental Health Perspectives, 113(6):693-699.

Arora, S. and Cason, T. N. (1999). Do Community Characteristics Influence Environmental Outcomes? Evidence from the Toxics Release Inventory. Southern Economic Journal, 65(4):691-716.

Ash, M., Boyce, J. K., Chang, G., and Scharber, H. (2013). Is Environmental Justice Good for White Folks? Industrial Air Toxics Exposure in Urban America. Social Science Quarterly, 94(3):616-636.

Ash, M. and Fetter, T. R. (2004). Who Lives on the Wrong Side of the Environmental Tracks? Evidence from the EPA's Risk-Screening Environmental Indicators Model. Social Science Quarterly, 85(2):441-462.

Been, V. and Gupta, F. (1997). Coming to the nuisance or going to the barrios? A longitudinal analysis of environmental justice claims. Ecology Law Quarterly, 24(1):1-56.

Bell, M. L. and Ebisu, K. (2012). Environmental inequality in exposures to airborne particulate matter components in the United States. Environmental Health Perspectives, 120(12):1699-704.

Boer, J. T., JR, P. M., Sadd, J. L., and Snyder, L. D. (1997). Is there environmental racism ? The demographics of hazardous waste in Los Angeles County : Research on the environment. Social Science Quarterly, 78(4):793-810.

Boone, C. (2002). An assessment and explanation of environmental inequality in Baltimore. Urban Geography, 23:581-595.

Bouwes, N. W., Hassur, S. M., and Shapiro, M. D. (2003). Information for Empowerment: The EPA's Risk-Screening Environmental Indicators Project. In Boyce, J. K. and Shelley, B. G., editors, Natural Assets: Democratizing Environmental Ownership. Princeton Island Press, Washington D.C.

Bowen, W. M., Salling, M. J., Haynes, K. E., and Cyran, E. J. (1995). Toward Environmental Justice: Spatial Equity in Ohio and Cleveland. Annals of the Association of American Geographers, 85(4):641-663.

Boyce, J. K. (2007). Inequality and Environmental Protection. In Baland, J., Bardhan, P., and Bowles, S., editors, Inequality, Collective Action, and Environmental Sustainability. Princeton University Press, Princeton, NJ.

Boyce, J. K. and Pastor, M. (2012). Cooling the Planet, Clearing the Air: Climate Policy, Carbon Pricing, and Co-Benefits. Economics for Equity and the Environment, Portland, OR.

Brochu, P. J., Yanosky, J. D., Paciorek, C. J., Schwartz, J., Chen, J. T., Herrick, R. F., and Suh, H. H. (2011). Particulate air pollution and socioeconomic position in rural and urban areas of the Northeastern United States. American Journal of Public Health, 101 Suppl:S224-30.

Brooks, N. and Sethi, R. (1997). The distribution of pollution: Community characteristics and exposure to air toxics. Journal of Environmental Economics and Management, 32(2):233-250.

Bullard, R. D. (1983). Solid Waste Sites and the Black Houston Community. Sociological Inquiry, 53:273-288.

Bullard, R. D., Mohai, P., Saha, R., and Wright, B. (2008). Toxic Wastes and Race at Twenty: Why Race still matters after all of these years. Environmental Law, 38:371-411. 
Commission for Racial Justice (1987). Toxic Wastes and Race in the United States. A National Report on the Racial and Socio-Economic Characteristics of Communities with Hazardous Waste Sites. United Church of Christ.

Downey, L. (2007). US Metropolitan-area Variation in Environmental Inequality Outcomes. Urban Studies, 44(5-6):953-977.

Downey, L., Dubois, S., Hawkins, B., and Walker, M. (2008). Environmental Inequality in Metropolitan America. Organization \& Environment, 21(3):270-294.

Downey, L. and Hawkins, B. (2008). Single-Mother Families and Air Pollution : A National Study. Social Science Quarterly, 89(2):523-536.

Fredriksson, P. G. and Millimet, D. L. (2002). Strategic Interaction and the Determination of Environmental Policy across U.S. States. Journal of Urban Economics, 51(1):101-122.

Hird, J. A. and Reese, M. (1998). The Distribution of Environmental Quality: An Empirical Analysis. Social Science Quarterly, 79(4):639-716.

Houston, D., Li, W., and Wu, J. (2013). Disparities in Exposure to Automobile and Truck Traffic and Vehicle Emissions Near the Los Angeles-Long Beach Port Complex. American Journal of Public Health, pages 1-9.

Konisky, D. M. (2007). Regulatory Competition and Environmental Enforcement: Is There a Race to the Bottom. American Journal of Political Science, 51(4):853-872.

Lopez, R. (2002). Segregation and black/white differences in exposure to air toxics in 1990. Environmental Health Perspectives, 110 Suppl:289-95.

Marshall, J. D. (2008). Environmental inequality: Air pollution exposures in California's South Coast Air Basin. Atmospheric Environment, 42(21):5499-5503.

Milman, A. (2006). Geographic pollution mapping of power plant emissions to inform ex-ante environmental justice analyses. Journal of Environmental Planning and Management, 49(4):587-604.

Mohai, P. and Bryant, B. (1992). Environmental racism: Reviewing the evidence. In Race and the Incidence of Environmental Hazards: A Time for Discourse. Westview Press, Boulder, CO.

Mohai, P., Lantz, P. M., Morenoff, J., House, J. S., and Mero, R. P. (2009). Racial and socioeconomic disparities in residential proximity to polluting industrial facilities: evidence from the Americans' Changing Lives Study. American Journal of Public Health, 99 Suppl 3:S649-56.

Mohai, P. and Saha, R. (2007). Racial Inequality in the Distribution of Hazardous Waste : A National-Level. Social Problems, 54(3):343-370.

Morello-Frosch, R. and Jesdale, B. M. (2005). Separate and Unequal: Residential Segregation and Estimated Cancer Risks Associated with Ambient Air Toxics in U.S. Metropolitan Areas. Environmental Health Perspectives, 114(3):386-393.

Morello-Frosch, R., Pastor, M., Porras, C., and Sadd, J. (2002). Environmental justice and regional inequality in southern California: implications for future research. Environmental Health Perspectives, 110 Suppl:149-54.

Morello-Frosch, R., Pastor, M., and Sadd, J. (2001). Environmental Justice and Southern California's "Riskscape": The Distribution of Air Toxics Exposures and Health Risks among Diverse Communities. Urban Affairs Review, 36(4):551-578.

Norton, J. M., Wing, S., Lipscomb, H. J., Kaufman, J. S., Marshall, S. W., and Cravey, A. J. (2007). Race, Wealth, and Solid Waste Facilities in North Carolina. Environmental Health Perspectives, 115(9):1344-1350. 
Oakes, J. (1997). The Location of Hazardous Waste Facilities. PhD thesis, University of Massachusetts, Amherst.

Pastor, M., Morello-Frosch, R., and Sadd, J. L. (2005). The air is always cleaner on the other side: race, space and ambient air toxics exposure in California. Journal of Urban Affairs, 27(2):127-148.

Pastor, M., Sadd, J., and Hipp, J. (2001). Which Came First? Toxic Facilities, Minority Move-In, and Environmental Justice. Journal of Urban Affairs, 23(1):1-21.

Perlin, S. A., Setzer, R. W., Creason, J., and Sexton, K. (1995). Distribution of industrial air emissions by income and race in the United States: an approach using the toxic release inventory. Environmental Science 83 Technology, 29(1):69-80.

Sadd, J. L., Pastor, M., Boer, J. T., and Snyder, L. D. (1999). "Every Breath You Take... ": The Demographics of Toxic Air Releases in Southern California. Economic Development Quarterly, 13(2):107-123.

Saha, R. and Mohai, P. (2005). Historical Context and Hazardous Waste Facility Siting : Understanding Temporal Patterns in Michigan. Social Problems, 52(4):618-648.

Sheppard, E., Leitner, H., McMaster, R. B., and Tian, H. (1999). GIS-based measures of environmental equity: exploring their sensitivity and significance. Journal of Exposure Analysis and Environmental Epidemiology, 9(1):18-28.

Sicotte, D. and Swanson, S. (2007). Whose Risk in Philadelphia ? Proximity to Unequally Hazardous Industrial Facilities. Social Science Quarterly, 88(2):515-534.

Stretesky, P. and Hogan, M. J. (1998). Environmmental Justice: An Analysis of Superfund Sites in Florida. Social Problems, 45(2):268-287.

US Census (2007). Summary File 3, 2000 Census of Population and Housing. Technical Documentation, volume 8. US Census of Population and Housing.

US EPA (2012). EPA 's Risk-Screening Environmental Indicators (RSEI) Methodology (RSEI Version 2.3.1). Number May 2012. US Environmental Protection Agency.

Wilson, S. M., Fraser-Rahim, H., Williams, E., Zhang, H., Rice, L., Svendsen, E., and Abara, W. (2012). Assessment of the distribution of toxic release inventory facilities in metropolitan Charleston: an environmental justice case study. American Journal of Public Health, 102(10):1974-80. 


\section{Appendix}

Appendix Figure A.1.: EPA Regions



\begin{tabular}{|c|c|c|c|c|c|c|c|c|c|}
\hline $\begin{array}{l}\text { Region } 1 \\
\text { New England }\end{array}$ & $\begin{array}{l}\text { Region 2 } \\
\text { Northeast* }\end{array}$ & $\begin{array}{l}\text { Region 3 } \\
\text { Mid-Atlantic }\end{array}$ & $\begin{array}{l}\text { Region } 4 \\
\text { Southeast }\end{array}$ & $\begin{array}{l}\text { Region 5 } \\
\text { Midwest }\end{array}$ & $\begin{array}{l}\text { Region } 6 \\
\text { South Central }\end{array}$ & $\begin{array}{l}\text { Region } 7 \\
\text { Central Plains }\end{array}$ & $\begin{array}{l}\text { Region } 8 \\
\text { Central Mountains }\end{array}$ & $\begin{array}{l}\text { Region } 9 \\
\text { West, Southwest** }\end{array}$ & $\begin{array}{l}\text { Region 10 } \\
\text { Pacific Northwest }\end{array}$ \\
\hline Connecticut & New Jersey & Delaware & Alabama & Illinois & Louisiana & Iowa & Colorado & Arizona & Alaska \\
\hline Maine & New York & DC & Florida & Indiana & Arkansas & Kansas & Montana & California & Idaho \\
\hline Massachusetts & & Maryland & Georgia & Michigan & Oklahoma & Missouri & North Dakota & Hawaii & Oregon \\
\hline New Hampshire & & Pennsylvania & Kentucky & Minnesota & New Mexico & Nebraska & South Dakota & Nevada & Washington \\
\hline Rhode Island & & Virginia & Mississippi & Ohio & Texas & & Utah & & \\
\hline Vermont & & West Virginia & $\begin{array}{l}\text { North Carolina } \\
\text { South Carolina } \\
\text { Tennessee }\end{array}$ & Wisconsin & & & Wyoming & & \\
\hline
\end{tabular}

*** Excluding Pacific Territories which are also part of EPA region 9. 
Appendix Table A.1: Summary Statistics ( $\mathrm{N}=143,716$ block groups in urbanized areas)

\begin{tabular}{lccccc}
\hline \hline Variable & Mean & $\mathrm{p} 25$ & $\mathrm{p} 50$ & $\mathrm{p} 75$ & $\mathrm{p} 90$ \\
\hline Exposure & 4434 & 299 & 1281 & 4210 & 11435 \\
$\ln (1+$ Exposure) & 6.80912 & 5.70259 & 7.15643 & 8.34535 & 9.34454 \\
Median Income/100k & 0.49358 & 0.32115 & 0.44913 & 0.61667 & 0.80674 \\
Percent White & $62.7 \%$ & $36.6 \%$ & $75.1 \%$ & $90.5 \%$ & $95.9 \%$ \\
Percent African American & $13.5 \%$ & $0.4 \%$ & $3.2 \%$ & $12.8 \%$ & $46.6 \%$ \\
Percent Hispanic & $16.5 \%$ & $1.5 \%$ & $5.4 \%$ & $18.8 \%$ & $55.3 \%$ \\
Percent Other Minority & $5.4 \%$ & $0.5 \%$ & $2.4 \%$ & $6.1 \%$ & $13.3 \%$ \\
\hline \hline
\end{tabular}

Notes: Summary statistics are population-weighted block group averages. Exposure is censored at the p97 value.

Appendix Table A.2: Summary Statistics by EPA region (blockgroup averages)

\begin{tabular}{|c|c|c|c|c|c|c|c|c|c|c|c|}
\hline & National & $\begin{array}{l}\text { Region } 1 \\
\text { New } \\
\text { England }\end{array}$ & $\begin{array}{l}\text { Region } 2 \\
\text { Northeast }\end{array}$ & $\begin{array}{l}\text { Region } 3 \\
\text { Mid- } \\
\text { Atlantic }\end{array}$ & $\begin{array}{l}\text { Region } 4 \\
\text { Southeast }\end{array}$ & $\begin{array}{l}\text { Region } 5 \\
\text { Midwest }\end{array}$ & $\begin{array}{l}\text { Region } 6 \\
\text { South } \\
\text { Central }\end{array}$ & $\begin{array}{l}\text { Region } 7 \\
\text { Central } \\
\text { Plains }\end{array}$ & $\begin{array}{l}\text { Region } 8 \\
\text { Central } \\
\text { Moun- } \\
\text { tains } \\
\end{array}$ & $\begin{array}{l}\text { Region } 9 \\
\text { West, } \\
\text { South- } \\
\text { west }\end{array}$ & $\begin{array}{l}\text { Region } 10 \\
\text { Pacific } \\
\text { North- } \\
\text { west } \\
\end{array}$ \\
\hline Exposure & 4434 & 2320 & 2739 & 5542 & 2333 & 8141 & 8003 & 4919 & 2703 & 2556 & 4536 \\
\hline $\ln (1+$ Exposure $)$ & 6.80912 & 6.58879 & 6.91616 & 7.18936 & 6.21002 & 8.15872 & 7.67586 & 6.98098 & 6.51999 & 6.04893 & 6.97834 \\
\hline MedInc/100k & 0.49358 & 0.55968 & 0.53568 & 0.52172 & 0.44830 & 0.50386 & 0.44441 & 0.47617 & 0.50958 & 0.52411 & 0.49907 \\
\hline CBSA MedInc/100k & 0.44006 & 0.51503 & 0.49767 & 0.46188 & 0.38533 & 0.44257 & 0.37261 & 0.39322 & 0.46759 & 0.48414 & 0.46972 \\
\hline Percent White & $62.7 \%$ & $81.0 \%$ & $58.4 \%$ & $70.2 \%$ & $65.1 \%$ & $73.0 \%$ & $51.5 \%$ & $79.1 \%$ & $78.6 \%$ & $47.3 \%$ & $79.4 \%$ \\
\hline Percent African American & $13.5 \%$ & $5.8 \%$ & $15.8 \%$ & $19.7 \%$ & $21.3 \%$ & $15.4 \%$ & $15.2 \%$ & $12.7 \%$ & $2.8 \%$ & $6.3 \%$ & $3.2 \%$ \\
\hline Percent Hispanic & $16.5 \%$ & $7.5 \%$ & $16.7 \%$ & $4.8 \%$ & $9.8 \%$ & $6.8 \%$ & $27.9 \%$ & $4.0 \%$ & $13.2 \%$ & $30.8 \%$ & $6.9 \%$ \\
\hline Percent Other Minority & $5.4 \%$ & $3.9 \%$ & $7.0 \%$ & $3.8 \%$ & $2.3 \%$ & $3.2 \%$ & $3.8 \%$ & $2.5 \%$ & $3.5 \%$ & $12.4 \%$ & $7.2 \%$ \\
\hline \%White*LowInc & $21.5 \%$ & $31.7 \%$ & $18.5 \%$ & $23.9 \%$ & $21.0 \%$ & $24.7 \%$ & $14.8 \%$ & $25.9 \%$ & $32.7 \%$ & $17.1 \%$ & $34.8 \%$ \\
\hline \%Whte*HighInc & $41.1 \%$ & $49.3 \%$ & $39.9 \%$ & $46.3 \%$ & $44.1 \%$ & $48.3 \%$ & $36.7 \%$ & $53.2 \%$ & $45.9 \%$ & $30.2 \%$ & $44.6 \%$ \\
\hline \%Africa American*LowInc & $9.9 \%$ & $4.8 \%$ & $12.5 \%$ & $14.5 \%$ & $14.4 \%$ & $12.3 \%$ & $10.5 \%$ & $9.8 \%$ & $1.9 \%$ & $4.5 \%$ & $2.4 \%$ \\
\hline \%AfricanAmerican*HighInc & $3.6 \%$ & $1.0 \%$ & $3.3 \%$ & $5.2 \%$ & $6.9 \%$ & $3.1 \%$ & $4.7 \%$ & $3.0 \%$ & $0.9 \%$ & $1.9 \%$ & $0.8 \%$ \\
\hline \%Hispanic*LowInc & $11.0 \%$ & $6.4 \%$ & $13.5 \%$ & $3.3 \%$ & $5.3 \%$ & $4.9 \%$ & $17.5 \%$ & $2.6 \%$ & $9.6 \%$ & $21.7 \%$ & $4.9 \%$ \\
\hline \%Hispanic*HighInc & $5.5 \%$ & $1.1 \%$ & $3.2 \%$ & $1.4 \%$ & $4.5 \%$ & $1.9 \%$ & $10.4 \%$ & $1.4 \%$ & $3.7 \%$ & $9.1 \%$ & $2.1 \%$ \\
\hline \%Othermin*LowInc & $2.6 \%$ & $2.4 \%$ & $4.0 \%$ & $1.6 \%$ & $0.9 \%$ & $1.5 \%$ & $1.5 \%$ & $1.2 \%$ & $1.9 \%$ & $5.9 \%$ & $4.0 \%$ \\
\hline \%Othermin*HighInc & $2.8 \%$ & $1.5 \%$ & $3.1 \%$ & $2.1 \%$ & $1.4 \%$ & $1.7 \%$ & $2.3 \%$ & $1.3 \%$ & $1.5 \%$ & $6.5 \%$ & $3.2 \%$ \\
\hline N(Blockgroups & 143765 & 8599 & 17512 & 15911 & 19608 & 26149 & 14853 & 5323 & 4167 & 23535 & 5578 \\
\hline Groups(CBSAs) & 398 & 18 & 16 & 38 & 97 & 70 & 49 & 19 & 22 & 36 & 23 \\
\hline
\end{tabular}

Notes: Summary statistics are population-weighted block group averages. Exposure is censored at the p97 value. 
Appendix Figure A.2: Percent Shares in Income Strata by EPA Region



Midwest

South Central

Central Plains

Central Mountains



West/Southwest

Pacific Northwest

National

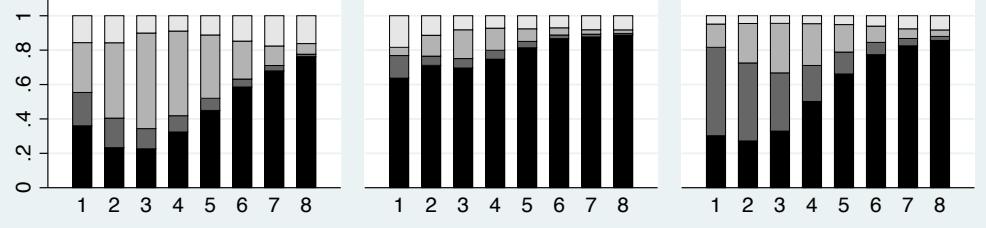

Whites

African Americans

Hispanics

Other Minority

Note: Income strata are defined as follows

1: below $\$ 10 \mathrm{k}$;

2: $\$ 10-15 \mathrm{k}$;

3: $\$ 15-25 \mathrm{k}$;

4: $\$ 25-35 \mathrm{k}$;

5: $\$ 35-50 \mathrm{k}$;

6: $\$ 50-75 \mathrm{k}$

7: $\$ 75-100 \mathrm{k}$

8: above $\$ 100 \mathrm{k}$ 